\title{
DASAR PERTIMBANGAN HUKUM MAHKAMAH AGUNG RI TENTANG WASIAT WAJIBAH
}

\author{
Sidik Tono \\ Dosen Prodi Hukum Islam FIAI-UII Yogyakarta \\ Email: sidiktono@gmail.com
}

\section{ABSTRACT}

Judgments of the Supreme Court RI relating to wasiat wajibah was many, especially in the last of 10 years. In this study, researchers focused on the legal considerations of the Supreme Court relating to wasiat wajibah that finally being jurisprudence. This study aims to provide an explanation of legal consideration basic used in the decisions of the Supreme Court in the case of wasiat wajibah. This study examines the consistency of legal consideration used by Supreme Court in the similar case, especially in the duration 2006-2013.

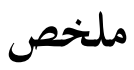

وكانت الأحكام الصادرة عن المحكمة العليا لجمهورية إندونيسيا المتعلقة بوصية واجبةعديدة، وخاصة في آخر • اعاما. في هذه الدراسة، ركز الباحث على الاعتبارات القانونية للمحكمة العليا فيما يتعلق بوصية واجبة كالفقهأخيرا. وتمدف هذه الدراسة إلى تقديم تفسير أسس الاعتباراتالقانونية المستخدمة في قرارات المحكمة العليا في قضية وصية واجبة. تحدف هذه الدراسة إلى اتساق الاعتبارات القانونية

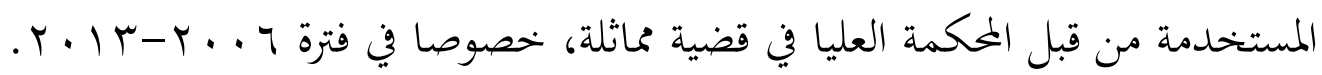

Keywords: Putusan MA, wasiat wajibah, yurisprudensi.

\section{A. Pendahuluan}

Masyarakat Indonesia adalah masyarakat yang kompleks dan plural, sehingga adanya perbedaaan agama dalam anggota keluarga pada sebuah keluarga ter- 
tentu bisa dikatakan merupakan suatu kewajaran. Hal ini dapat dilihat dari realitas yang menunjukkan banyaknya pernikahan antara pria/wanita Islam dengan non-muslim. Selanjutnya anak dari hasil perkawinan ini, baik yang mengikuti agama yang muslim atau yang non-muslim, maka akan terjadi perbedaan agama dalam satu keluarga. Melihat fakta yang demikian inilah, penting kiranya untuk membahas hukum bagi ahli waris non-muslim dalam konteks hukum Islam sebagai wujud rahmatan lil 'alamin dan sebagai perwujudan hukum nasional Indonesia yang yang termanifestasi dalam institusi keadilan, yang dapat mengakomodasi dan menjamin keadilan tanpa memandang agama.

Penyelesaian masalah ahli waris non-muslim merupakan salah satu dari penerapan fungsi hukum, Steven Vago menyatakan bahwa:

"Why do we need law, and what does it do for society? More specifically what function does law perform? As with the definition of law, there is no agreement among scholars of law and society on the precise functions, nor is there consensus on their relative weight and importance. A variety of functions are highlited in the literature (see, for example, Aubert 1969: 11, Bredeneir, 1962: 74, Mermin, 1973: 5-10, Nader and Todd, 1978: 1, Pollack, 1979: 669, and Samford, 1989: 116-120) depending on the conditions under which law operates at a particular time and place. The recurrent themes include social control, dispute settlement, and social engineering". ${ }^{1}$

Memang penentuan fungsi hukum dalam masyarakat belum ada kesepakatan dari pakar hukum, hal ini bergantung dari kondisi masyarakat di mana hukum itu berlaku sesuai dengan tempat dan waktu. Namun penegasan di atas menyebutkan ada tiga fungsi dari hukum, yaitu social control (kontrol sosial), dispute settlement (penyelesaian sengketa), dan social engineering (rekayasa sosial). Jadi hukum akan dapat berfungsi sebagai sarana yang cukup efektif dalam menyelesaikan sengketa dan sekaligus memberikan solusi dalam penyelesaian masalah yang terjadi dalam masyarakat.

Dalam hal ini, Wasiat Wajibah dapat menjadi salah satu cara, sebagai tindakan negara untuk memindahkan kepemilikan harta benda dari seseorang kepada pihak lain dengan cara sah, juga menjadi salah satu alternatif untuk

1 Steven Vago, Law and Society, (New Jersey: Prentice Hall Englewood Cliffs, tt), hal. 12. 
memberikan bagian kepada pihak-pihak yang tidak mendapatkan harta waris, yang pelaksanaannya setelah matinya pemilik harta.

Bandingkan dalam pengertian wasiat selama ini adalah tindakan seseorang memberikan hak kepada orang lain untuk memiliki sesuatu, baik berupa benda atau manfaat secara sukarela (tabarru'i) yang pelaksanaannya ditangguhkan setelah kematian orang yang memberi wasiat. ${ }^{2}$ Sebagai salah satu cara pemindahan kepemilikan, wasiat hanya bisa dilaksanakan sesudah orang yang berwasiat meninggal dunia. ${ }^{3}$ Pada dasarnya, wasiat ini dilakukan dengan kemauan hati dalam keadaan apapun. Sehingga perbedaan antara wasiat dan Wasiat Wajibah pada dasarnya terletak pada penekanan "tindakan negara" melalui institusi hukum.

Dan umat Islam sangat mengharapkan berlakunya hukum Islam di Indonesia, sebab Islam selalu dapat memberi solusi terhadap berbagai masalah, salah satunya adalah masalah bagian ahli waris non-muslim di Indonesia yang dapat diakomodasi dengan hukum wasiat atau Wasiat Wajibah, sehingga permasalahan di atas menjadi menarik dan penting untuk diteliti lebih mendalam, yakni satu aspek dari hukum kewarisan Islam sebagai salah satu bagian pemikiran dalam pembentukan hukum waris dan wasiat nasional, dengan memperhatikan budaya atau kebiasaan yang hidup di masyarakat Indonesia. Karena itu, secara khusus penelitian ini berusaha mengakaji Wasiat Wajibah sebagai alternatif mengakomodasi bagian ahli waris non-muslim di Indonesia berdasarkan putusan Mahkamah Agung Republik Indonesia.

Sebagai Pengadilan Negara Tertinggi, Mahkamah Agung merupakan pengadilan kasasi yang bertugas membina keseragaman dalam penerapan hukum melalui putusan kasasi dan peninjauan kembali menjaga agar semua hukum dan undang-undang diseluruh wilayah negara RI diterapkan secara adil, tepat dan benar. Disamping tugasnya sebagai Pengadilan Kasasi, Mahkamah Agung berwenang memeriksa dan memutuskan pada tingkat pertama dan terakhir, yaitu semua sengketa tentang kewenangan mengadili dan permohonan peninjauan kembali putusan pengadilan yang telah memperoleh kekuatan hukum tetap. ${ }^{4}$ Erat kaitannya dengan fungsi peradilan ialah hak uji materiil, yaitu wewenang

2 Ahmad Rofiq, Hukum Islam di Indonesia, (Jakarta: PT. Raja Grafindo Persada, 2003), hal. 439.

3 Muhammad Hasbi Ash Shiddiqy, Fikihul Mawaris, (Jakarta: Bulan Bintang, 1973), hal. 291.

4 Lihat Pasal 28, 29,30,33 dan 34 Undang-undang Mahkamah Agung No. 14 Tahun 1985 
menguji/menilai secara materiil peraturan perundang-undangan dibawah Undang-undang tentang hal apakah suatu peraturan ditinjau dari isinya (materinya) bertentangan dengan peraturan dari tingkat yang lebih tinggi. ${ }^{5}$

Putusan-putusan Mahkamah Agung RI yang berkaitan dengan wasiat wajibah sudah cukup banyak terutama dalam 10 tahun terakhir. Pada penelitian ini peneliti fokus pada pertimbangan hukum yang dipakai sebagai dasar putusan-putusan Mahkamah Agung RI yang berkaitan dengan wasiat wajibah yang pada gilirannya menjadi yurisprudensi, sehingga akan ditemukan konsistensi atau inkonsistensinya dasar pertimbangannya, atau pada kasus-kasus tertentu dasar pertimbangan hukum selalu berubah atau tidak.

Berdasarkan berbagai uraian dalam latar belakang masalah di atas, maka rumusan masalah dari penelitian ini adalah: Bagaimana pertimbangan hukum dari putusan-putusan Mahkamah Agung RI tentang Wasiat Wajibah di Indonesia? Berangkat dari rumusan masalah di atas, maka secara khusus penelitian ini bertujuan untuk memberikan penjelasan tentang dasar pertimbangan hukum yang dipakai dalam putusan-putusan Mahkamah Agung RI tentang Wasiat Wajibah. Dari temuan ini dapat dipahami tentang dasar hukum Islam yang menjadi sumber dasar atas pertimbangan hukumnya dan konsistensi dari putusan-putusan yang sama dari kasus-kasus yang sejenis, khususnya putusan pada delapan tahun terakhir, yaitu tahun 2006 - 2013.

\section{B. Tinjauan Penelitian Terdahulu}

Sejauh penelusuran peneliti telah berkembang berkembang pemikiran mengenai Wasiat Wajibah, bahkan telah banyak dipublikasikan, baik dalam bentuk disertasi, tesis dan penelitian ilmiah lainnya. Ada beberapa yang telah peneliti kaji dari hasil penelitian terdahulu, yaitu; penelitian Dolianti dkk, (2013), tentang Pembagian Harta Waris Orang Yang Berbeda Agama (Suatu Studi Atas Putusan Mahkamah Agung RI Nomor 51 K/AG/1999), ${ }^{6}$ kemudian penelitian yang sama diteliti oleh Maulana, (2013), tentang Kajian Yuridis Tentang Wasiat Wajibah Kepada Ahli Waris Non Muslim Menurut Hukum Waris Islam (Studi Putus-

5 Lihat Pasal 31 Undang-undang Mahkamah Agung Nomor 14 Tahun 1985.

6 Dolianti, dkk, "Pembagian Harta Waris Orang Yang Berbeda Agama (Suatu Studi Atas Putusan Mahkamah Agung RI Nomor 51 K/AG/1999)", dalam Tesis, (Bengkulu: Fakultas Hukum, 2013). 
an Mahkamah Agung RI Nomor 368. K/AG/1995), 7 selanjutnya penelitian Nadia (2012), tentang Studi Kasus Putusan Mahkamah Agung Republik Indonesia No 16 K/Ag/2010 Tentang Hak Mewaris Istri Non Muslim dari Suami Yang Beragama Islam dihubungkan Dengan Hukum Waris Islam dan Instruksi Presiden Nomor 1 Tahun 1991 Tentang Kompilasi Hukum Islam, ${ }^{8}$ kemudian penelitian Iscahyanto, (2005), tentang Analisis Yuridis Wasiat Wajibah Sebagai Salah Satu Cara Mendapatkan Bagian Bagi Anak Angkat (Studi Kasus Putusan Nomor: 1326/Pdt.G/2006/PA.TA dan Putusan Nomor : 07/Pdt.G/2008/PTA.Sby). ${ }^{9}$ Peneliti juga mengkaji Susanti (2012), tentang Wasiat Wajibah Bagi Anak Angkat Menurut Kompilasi Hukum Islam (Studi Kasus Putusan Mahkamah Agung Nomor 338 K/AG/2009). ${ }^{10}$

Penelitian-penelitian diatas masih merupakan putusan yang secara parsial atau fokus pada kasus tertentu saja, yaitu pada kasus beda agama, istri yang beda agama dan kasus anak angkat. yang membedakan penelitian ini dengan penelitian-penelitian sebelumnya adalah: Pertama, pada penelitian ini peneliti ingin mengkaji secara komprehensif tentang putusan Mahkamah Agung tentang adanya wasiat wajibah yang secara khusus diputuskan pada tahun 20012012 dengan berbagai kasus. Kedua, adanya kajian mendalam tentang Hukum Islam itu sendiri berkaitan dengan harta peninggalan bagi anggota keluarga yang terhalang untuk mendapatkan bagian harta peninggalan, sehingga titik masalah bisa ditemukan dan bisa dijadikan dasar bagi masyarakat atau hakim bila menemukan masalah yang sama dengan kasus yang berbeda-beda. Dan ketiga, selain dikaji dengan pendekatakan yuridis normatif, penelitian ini juga menggunakan pendekatan hermeneutika hukum, yaitu sebuah metode in-

7 Zaldin Abdi Maulana, "Kajian Yuridis Tentang Wasiat Wajibah Kepada Ahli Waris Non Muslim Menurut Hukum Waris Islam (Studi Putusan Mahkamah Agung RI Nomor 368. K/AG/1995)", dalam Tesis, (Jember: Universitas Jember, 2013).

8 Nike Nadia, "Studi Kasus Putusan Mahkamah Agung Republik Indonesia No 16 K/ Ag/2010 Tentang Hak Mewaris Istri Non Muslim dari Suami Yang Beragama Islam Dihubungkan Dengan Hukum Waris Islam dan Instruksi Presiden Nomor 1 Tahun 1991 Tentang Kompilasi Hukum Islam", dalam Repository Jurnal Fakultas Hukum, (Bandung: Universitas Padjadjaran, 20 Maret 2013).

9 Dheddy Iscahyanto, “Analisis Yuridis Wasiat Wajibah Sebagai Salah Satu Cara Mendapatkan Bagian Bagi Anak Angkat (Studi Kasus Putusan Nomor : 1326/Pdt.G/2006/ PA.TA dan Putusan Nomor : 07/Pdt.G/2008/PTA.Sby)", dalam Tesis, (Yogyakarta: UGM, 2005).

10 Fitri Susanti, “Wasiat Wajibah Bagi Anak Angkat Menurut Kompilasi Hukum Islam (Studi Kasus Putusan Mahkamah Agung Nomor 338 K/AG/2009)", dalam Tesis, (Yogyakarta: UGM, 2012). 
terpretasi terhadap tek yang secara filosofis, mempuyai tugas ontologis yaitu menggambarkan hubungan yang tidak dapat dihindari antara teks dan pembaca, masa lalu dan masa sekarang, yang memungkinkan untuk memahami kejadian yang pertama kali (genuine).

\section{Kerangka Teoritik}

Untuk menjelaskan konsep Wasiat Wajibah, peneliti telah mengajukan tiga pokok masalah. Untuk menjawab pokok masalah diatas, peneliti menggunakan teori teori maslahah al-syatibi mengenai maqasid al-syari'ah (tujuan hukum Islam). Sebelum menjelaskan secara detail tentang teori ini, peneliti menjelaskan lebih lebih dulu tentang wasiat dan wasiat wajibah.

\section{Pengertian Wasiat dan Wasiat Wajibah}

Masalah wasiat ini telah banyak disinggung dalam berbagai sistem hukum, ${ }^{11}$ mulai dari hukum adat, hukum perdata/Burgerlijk Wetboek (BW), maupun dalam hukum Islam.

Kata wasiat dalam Kamus Besar Bahasa Indonesia berarti pesan terakhir yang disampaikan oleh orang yang akan meninggal, biasanya berkenaan dengan harta kekayaan atau lainnya ${ }^{12}$. Sedangkan wasiat dalam Kompilasi Hukum Islam adalah pemberian suatu benda dari pewaris kepada orang lain atau lembaga yang akan berlaku setelah pewaris neninggal dunia. Ada beberapa definisi wasiat oleh para fuqaha' yang intinya adalah pemberian hak milik secara sukarela yang pelaksanaannya setelah pemberinya meninggal dunia, baik berupa barang, piutang atau manfaat ${ }^{13}$. Adapun definisi wasiat yang tanpa

11 Sistem hukum adalah suatu kesatuan komponen-komponen yang berada di dalam hukum, yang masing-masing komponen tersebut saling berhubungan satu sama lain. Hukum sebuah sistem, berarti di dalamnya terdiri atas komponen atau unsur-unsur yang saling bekerja sedemikian rupa sehingga membentuk suatu pola dengan ciri-ciri tersendiri. Umumnya para ahi hukum berpendapat bahwa dalam sistem hukum terdapat tiga komponen penting yang saling melengkapi dan ketergantungan, yaitu komponen struktur, substansi dan kultur. Lihat Krisnajadi, Bab-bab Pengantar Ilmu Hukum, (Bandung: STHB, 1989), hal. 23.

12 Departeman Pendidikan dan Kebudayaan, Kamus Besar Bahasa Indonesia, cet IX (Jakarta: Balai Pustaka, 1997), hal. 1126.

13 Fathurrahman Djamil, "Wasiat: Makna, Urgensi dan Kedudukannya dalam Islam", Jurnal Mimbar Hukum, No. 38 Th. IX (1999), hal. 5. Juga perhatikan dalam: Abdul Aziz Dah- 
mengkaitkan kata 'sukarela' adalah definisi Ibnu Rusyd yaitu pemberian harta dari seorang kepada orang lain, atau kepada beberapa orang, sesudah meninggalnya orang tersebut, atau membebaskan hambanya, baik dijelaskan dengan kata-kata wasiat atau tidak ${ }^{14}$.

Adapun definisi Wasiat Wajibah dalam Ensiklopedi Hukum Islam adalah suatu wasiat yang diperuntukkan kepada para ahli waris atau kerabat yang tidak memperoleh bagian harta warisan dari orang yang wafat, karena adanya suatu halangan syara' ${ }^{\prime 15}$. Hasby Ash Shiddieqy ${ }^{16}$ menjelaskan bahwa Wasiat Wajibah adalah wajib bagi kerabat-kerabat yang terhalang menerima harta pusaka. Selanjutnya beliau mengutip dari Al-Jashash dalam kitab Ahkamul Qur'an, menjelaskan bahwa Surat Al-Baqarah (2): 180 terang menunjuk kepada wajibnya wasiat bagi keluarga yang tidak mendapat pusaka. Perkataan "kutiba" dalam ayat itu bermakna "furida" (difardlukan) dan perkataan bi alma'ruf haqqan 'ala al-muttaqin, adalah suatu lafadz yang sangat kuat menunjuk kepada wajibnya wasiat, sehingga menurut beliau ma'ruf sebagai suatu hak (kewajiban) atas segala orang yang bertaqwa. Dan Allah SWT menjadikan pelaksanaan wasiat ini salah satu dari syarat taqwa menunjukkan kepada kewajiban wasiat itu. ${ }^{17}$

Sementara itu, dalam praktiknya, apabila terdapat ahli waris yang berlainan agama dengan pewaris, baik pewarisnya yang muslim atau ahli warisnya yang muslim, apabila diputuskan melalui pengadilan, maka dalam hal ini ahli waris akan mendapatkan bagian harta melalui jalan Wasiat Wajibah. ${ }^{18}$ Wasiat Wajibah inipun diserahkan kepada inisiatif hakim atau pembentukannya oleh negara. Karena Wasiat Wajibah pada dasarnya merupakan tindakan yang

lan (ed), Ensiklopedi Hukum Islam, Jilid. 6, Jakarta: Ichtiar Baru van Hove, hal. 1926.

14 Ibnu Rusyd, Bidayatul Mujtahid, Juz II, (Semarang: Usaha Keluarga, t.t.), hal. 252.

15 Abdul Aziz Dahlan (ed), Ensiklopedi Hukum Islam, (Jakarta: PT. Ichtiar Baru van Hoeve, 1996), hal. 1930.

16 TM. Hasbi Ash-Shiddiqy, Fiqih Mawaris, (Semarang: PT. Pustaka Rizki Putra, 1999), hal. 274.

17 Ibid. (Mengutip dari Ahkamul Qur'an I: 164, Tafsir Ar-Razi II: 111, dan tatimmah Ar-Raudhaun Nadhir IV: 107).

18 Wasiat Wajibah adalah suatu pemberian yang wajib diberikan kepada cucu-cucu yatim yang orang tuanya meninggal mendahului atau bersamaan kakeknya, sebesar bagian orang tuanya seandainya orang tuanya hidup dengan ketentuan tidak boleh melebihi 1/3 dari harta peninggalan, lihat majalah UNISIA Universitas Islam Indonesia 1979, Fatchurrahman, Washiyat Wajibah (Plaatsvervulling), hal. 7. 
dilakukan penguasa atau hakim sebagai aparat negara untuk memaksa atau memberi keputusan wajib bagi orang yang telah meninggal yang diberikan kepada orang tertentu dalam keadaan tertentu. ${ }^{19}$

\section{Teori Maslahah (Teori Keadilan Sosial Hukum Islam).}

Salah satu konsep penting dan fundamental yang menjadi pokok bahasan dalam filasafat hukum Islam adalah konsep maqasid at-tasyri' atau maqasid alsyari'ah yang menegaskan bahwa hukum Islam disyari'atkan untuk mewujudkan dan memelihara maslahat umat manusia. Konsep ini menghendaki lahirnya pemikiran yang proporsional tentang keadilan dalam kehidupan manusia, artinya bagaimana membentuk dan melaksanakan hukum sebagai upaya mewujudkan kemaslahatan manusia dalam arti luas. Konsep ini telah diakui oleh para ulama dan oleh karena itu mereka memformulasikan suatu kaidah yang cukup populer, "di mana ada maslahat, di sana terdapat hukum Allah." ${ }^{20}$ Teori maslahat di sini menurut Masdar F. Mas'udi sama dengan teori keadilan sosial dalam istilah filsafat hukum. ${ }^{21}$

Batasan yang selama ini dijabarkan oleh para ulama, seperti Ramadan alButhi ${ }^{22}$ atau al-Syatibi ${ }^{23}$ menurut penulis berkaitan dengan maslahat dalam artian yang sangat luas. Padahal sebagaimana diungkap Syaltut, maslahat sama seperti ijtihad yang selalu berubah menyesuaikan kondisi waktu dan zaman yang membutuhkan solusi hukum. Itu artinya, batasan untuk maslahat juga perlu dibuat lebih spesifik sesuai dengan kebutuhan dimana maslahat tersebut akan digunakan. Dalam konteks Indonesia, maka batasan maslahat yang berbasis budaya Indonesia mutlak untuk direalisasikan.

Jadi jelas bahwa yang fundamental dari bangunan pemikiran hukum Is-

19 Ahmad Rofiq, Hukum Islam di Indonesia, (Jakarta: PT. Raja Grafindo Persada, 2003), hal. 362.

20 Muhammad Sa'id Ramdan al-Buti, Dawabit al-Maslahah fi as-Syariah al-Islamiyah, (Beirut: Mu'assasah ar-Risalah,1977), hal.12.

${ }^{21}$ Masdar F. Mas'udi, “Meletakkan Kembali Maslahat Sebagai Acuan Syari'ah”, Jurnal Ilmu dan Kebudayaan Ulumul Qur'an, No.3, Vol. VI Th. (1995), hal. 97

22 Ramadhan al-Buthi, Dawabith al-Maslahah al-Syari'ah al-Islamiyah, (Beirut, Libanon: AlMuassasah al-Risalah, 2001), hal. 119-248.

${ }^{23}$ Muhammad Khalid Mas'ud, Islamic Legal Philosophy a Study of Abu Ishaq al-Shatibi's Life and Thought, (Delhi: International Publisher, 1989), hal. 159. 
lam adalah maslahat, maslahat manusia universal, atau "keadilan sosial". Tawaran ijtihadi, baik didukung dengan nas atau pun tidak, yang bisa menjamin terwujudnya maslahat kemanusiaan, dalam kacamata Islam adalah sah, dan umat Islam terikat untuk mengambilnya dan merealisasikannya. Sebaliknya, tawaran teoritik apa pun dan yang bagaimana pun, yang secara meyakinkan tidak mendukung terjaminnya maslahat, lebih lebih yang membuka kemungkinan terjadinya kemudaratan, dalam kacamata Islam, adalah fasid, dan umat Islam secara orang perorang atau bersama-sama terikat untuk mencegahnya. ${ }^{24}$

Dengan tawaran kaidah yang lebih menekankan pada substansi, yaitu maslahat-keadilan, bukan berarti segi formal dan tekstual dari ketentuan hukum harus diabaikan. Ketentuan legal-formal-tekstual yang sah, bagaimana pun, harus menjadi acuan tingkah laku manusia dalam kehidupan bersama, kalau tidak ingin menjadi anarki. Akan tetapi, pada saat yang sama, haruslah disadari sedalam-dalamnya bahwa patokan legal-formal dan tekstual hanyalah merupakan cara bagaimana cita maslahat, keadilan, itu diaktualisasikan dalam kehidupan nyata. Kalau dipertanyakan kedudukan hukum atau ketentuan-ketentuan legal-normatif yang ditawarkan oleh wahyu (teks Al-Quran atau hadis), kedudukannya adalah sebagai material yang - juga dengan logika maslahat sosial yang obyektif, bukan dengan logika kekuatan atau kepercayaan yang subyektif,- masih harus dibawa untuk ditentukan statusnya ke dalam lembaga permusyawaratan. Apabila kita berhasil membawanya sebagai bagian dari kesepakatan orang banyak, ia berfungsi sebagai hukum yang secara formalpositif mengikat. Akan tetapi, apabila gagal memperjuangkannya sebagai kesepakatan, daya ikatnya tentu saja hanya terbatas pada orang-orang yang mempercayainya. Dan daya ikat seperti ini paling jauh hanya bersifat moralsubyektif, tidak bisa sekaligus formal-obyektif.

Memang, dengan mempertaruhkan "maslahat dan sekaligus norma hukum yang bersumber padanya" pada ijma' lembaga syura, atau keputusan lembaga parlemen dalam terma ketata-negaraan modern, bukan tidak ada kelemahannya. Tidak jarang apa yang disebut kesepakatan lembaga syura, parlemen, ternyata hanya merupakan hasil rekayasa segelintir elit yang berkuasa. Akan tetapi inilah tantangan yang harus dihadapi oleh umat Islam, yang sebenarnya adalah juga tantangan bagi rakyat-manusia di mana pun mereka berada. Yakni,

\footnotetext{
24 Ibid., hal. 97.
} 
bagaimana mereka bisa mengusahakan tumbuhnya satu pranata kesepakatan umat, di mana rakyat- secara langsung atau melalui wakilnya- dapat mengemukakan pendapat dan pilihannya perihal tata-kehidupan yang menurut mereka lebih mencerminkan cita maslahat dan keadilan. ${ }^{25}$ Penegakan keadilan adalah aplikasi dari nilai-nilai kemaslahatan, namun bagaimana cara penegakan tersebut akan sangat bergantung pada kondisi wilayah dimana keadilan itu akan ditegakkan.

\section{Prosedur Penelitian}

Penelitian ini adalah masuk kategori penelitian hukum normatif yang berusaha meneliti hukum inconcreto (kenyataan hukum), dengan menjadikan putusan Mahkamah Agung sebagai kasus. Karena itu, titik berat dari penelitian ini adalah penelitian pustaka (library research) dan desain penelitian ini adalah penelitian kualitatif-deskriptif, yaitu sebuah penelitian yang berusaha mengungkap keadaan yang bersifat alamiah secara holistik. ${ }^{26}$ Penelitian kualitatif berupaya untuk menyajikan realitas sosial dan perspektifnya dari segi konsep, perilaku dan persepsi obyek yang diteliti. ${ }^{27}$

Adapun pendekatan yang digunakan dengan tiga pendekatan, yaitu pendekatan Hermeneutika Hukum, adalah ajaran filsafat mengenai hal mengerti memahami sesuatu, atau sebuah metode interpretasi terhadap teks dimana metode dan teknik menafsirkannya dilakukan secara holistik dalam bingkai keterkaitan antara teks, konteks, dan kontekstualisasi. ${ }^{28}$ Kemudian pendekatan yuridis-normatif, yaitu dengan melihat ketentuan perundang-undangan dan ketentuan hukum Islam yang berhubungan dengan masalah yang diteliti yakni masalah Wasiat Wajibah sebagai alternatif mengakomodasi anggota keluarga yang terhalang oleh waris di Indonesia, baik mengenai dasar-dasar yang melandasinya, pelaksanaannya, dan pembentukan hukumnya, ${ }^{29}$ atau kajian hukum

\footnotetext{
25 Ibid., hal. 98.

26 M. Sayuthi Ali, Metodologi Penelitian Agama; Pendekatan Teori dan Praktek, (Jakarta: PT Raja Grafindo Persada, 2002), hal. 18.

27 Lexy J. Moleong, Metode Penelitian Kualitatif, (Bandung: PT. Remaja Rosdakarya, 2007),

28 Jazim Hamidi, Hermeneutika Hukum, (Yogyakarta, UII Press: 2005), hal. 42-46.

29 Soerjono Soekanto dan Sri Mamudji, Penelitian Hukum Normatif, Suatu Tinjauan Singkat, (Jakarta: Raja Grafindo Persada, 2001), hal. 1; lihat juga Soerjono Soekanto, Pengantar
} hal. 6. 
doktrinal..$^{30}$ Dan pendekatan sosiologis, yaitu pendekatan disiplin ilmu dan teori ilmu sosial yang berfungsi untuk memecahkan masalah dalam penelitian hukum dengan membuat rekontruksi secara sistematis dan obyektif dengan cara mengumpulkan, mengevaluasi, memverifikasi, dan mensintesiskan data atau fakta untuk memperoleh kesimpulan yang kuat. ${ }^{31}$

Data yang diperlukan dan dikumpulkan dalam penelitian ini adalah berupa data primer dan data sekunder. Data primer yang dikumpukan adalah putusan-putusan Mahkamah Agung tentang Wasiat Wajibah dari tahun 2006-2012. Berdasarkan penelusuran peneliti dalam Direktori Putusan Mahkamah Agung Republik Indonesia yang di publikasikan dalam website resmi Mahkamah Agung, 19 putusan tersebut adalah: Putusan Nomor 216 K/TUN/2006, Putusan Nomor 102 K/AG/2006, Putusan Nomor 13 K/AG/2007, Putusan Nomor 318 K/AG/2008, Putusan Nomor 482 K/AG/2008, Putusan Nomor 307 K/ AG/2009, Putusan Nomor 338 K/AG/2009, Putusan Nomor 344 K/AG/2009, Putusan Nomor 356 K/AG/2009, Putusan Nomor 487 K/AG/2009, Putusan Nomor 538 K/AG/2009, Putusan Nomor 13 PK/AG/2010, Putusan Nomor 16 K/AG/2010, Putusan Nomor 145 K/AG/2010, Putusan Nomor 312 K/ AG/2010, Putusan Nomor 364 K/AG/2011, Putusan Nomor 443 K/AG/2011, Putusan Nomor 489 K/AG/2011, dan Putusan Nomor 207 K/AG/2012.

Teknik analisis yang digunakan dalam penelitian ini adalah content analisys. ${ }^{32}$ Yaitu data yang bersifat kualitatif, setelah dikumpulkan kemudian dianalisis dengan metode deskriptif-analitis, yaitu suatu metode dalam meneliti status kelompok manusia, suatu obyek, situasi serta kondisi, dan sistem pemikiran. Tujuan dari penelitian deskriptif-analitis ini adalah untuk memuat deskripsi yang berupa gambaran atau lukisan secara sistematis, faktual dan akurat mengenai fakta-fakta serta hubungan antar fenomena yang diselidiki. ${ }^{33}$

Penelitian Hukum, Cetakan ke-2, (Jakarta: UI Press, 1986), hal. 45.

30 Istilah ini digunakan oleh Soetandyo Wignjosoebroto, sebagaimana dinukil oleh: Bambang Sunggono, Metodologi Penelitian Hukum, Cetakan ke-2, (Jakarta: Rajawali Pres, 1998), hal. 43.

31 Husain Usman dan Purnomo Setiady Akbar, Metodologi Penelitian Sosial, Cetakan ke-3, (Jakarta: Bumi Aksara, 2003), hal. 4.

32 Content analysis adalah suatu metode untuk mengkaji dan menganalisis, obyektif dan kualitatif. Lihat: Fred N. Kerlenger, Asas-Asas Penelitian Behaviorial, (Jogjakarta: Gajah Mada University Press, 1996).

33 Muhammad Nazir, Metode Penelitian, (Jakarta: Ghalia Indonesia, 1988), hal. 63; lihat juga Soerjono Soekanto, Pengantar Penelitian Hukum, (Jakarta: UI Press, 1986), hal. 10. 
Analisis data ini dilakukan dengan model klasifikasi yang dipergunakan Miles dan Huberman ${ }^{34}$ yaitu model yang bergerak dalam tiga siklus kegiatan, yakni reduksi data, penyajian data, dan penarikan simpulan atau verifikasi.

\section{E. Pertimbangan Hukum Keputusan MA RI Tahun 2006 - 2012 ten- tang Wasiat Wajibah}

Pertimbangan Hukum dari Keputusan Mahkamah Agung tentang Wasiat Wajibah dari putusan tahun 2006 - 2012 secara umum mengacu pada Kompilasi Hukum Islam (KHI) berdasarkan Instruksi Presiden Republik Indonesia Nomor 1 Tahun 1991 dan ada beberapa pertimbangan hukum yang mengiringinya, diantaranya pertimbangan hukum yang mengacu pada hukum adat, Undangundang Nomor 4 Tahun 1979. Selain itu, berkaitan dengan wasiat wajibah, Mahkamah Agung secara khusus menerbitkan surat edaran Mahkamah Agung tanggal 7 April 1979 Nomor 2 Tahun 1979 Tentang Pengangkatan Anak yang konsekuensi hukumnya adalah adanya wasiat wajibah dalam hal pembagian harta peninggalan.

Pertimbangan hukum yang menjadi dasar atas putusan Mahkamah Agung mulai tahun 2006 sampai tahun 2012 khususnya tentang wasiat wajibah secara keseluruhan merujuk pada anak angkat. Kedudukan anak angkat ini mengacu pada Kompilasi Hukum Islam (KHI) khususnya pasal 171 huruf h yang menyebutkan bahwa anak angkat adalah anak yang dalam hal pemeliharaan untuk hidupnya sehari-hari, biaya pendidikan dan sebagainya beralih tanggungjawabnya dari orang tua asal kepada orang tua angkatnya berdasarkan putusan pengadilan.

Pada putusan-putusan Mahkamah Agung tersebut tidak ditemukan Hakim Agung merujuk pada paraturan lain selain KHI dan tidak pula ditemukan Hakim Agung membuat putusan sendiri diluar apa yang telah tertulis dalam KHI.

Pasal-pasal lain dalam KHI tentang wasiat adalah berkaitan dengan besaran pembagian wasiat. Besaran dalam Pasal 195 ayat (2), yaitu Wasiat hanya diperbolehkan sebanyak-banyaknya sepertiga dari harta warisan kecuali apabila semua ahli waris menyetujui. Besaran ini sama dengan besaran bagian untuk anak angkat yang diatur dalam pasal 209 ayat (2), yaitu terhadap anak angkat

34 Mattew B. Miles and A. Michael Huberman, Analisis Data Kualitatif: Buku Sumber tentang Metode-metode Baru, (Jakarta: UI Press, 1992), hal. 43. 
yang tidak menerima wasiat diberi wasiat wajibah sebanyak-banyaknya $1 / 3$ dari harta warisan orang tua angkatnya.

Putusan-putusan Mahkamah Agung yang selalu merujuk pada KHI tersebut bisa dipahami, sebab wasiat wajibah adalah peristiwa yang masuk dalam perkara hukum Islam khususnya pada bidang wasiat dan perkara ini tertulis dalam KHI. ${ }^{35}$ Istilah wasiat wajibah pertama kali diperkenalkan oleh Ibn Hazm yang menyatakan bahwa bagi tiap-tiap orang yang akan meninggal dan memiliki harta kekayaan, terutama kepada kerabat yang tidak memperoleh bagian warisan, karena kedudukan sebagai hamba, kekafirannya, atau ada hal yang menghalangi mereka dari hak kewarisan atau karena memang tidak berhak atas warisan. ${ }^{36}$

Wasiat wajibah adalah adalah wasiat yang pelaksanaannya tidak dipengaruhi atau tidak tergantung kepada kemauan atau kehendak yang meninggal dunia. Wasiat ini tetap harus dilaksanakan, baik diucapkan atau tidak diucapkan, baik dikehendaki atau tidak dikehendaki oleh yang meninggal dunia. Jadi, pelaksanaan wasiat tersebut tidak memerlukan bukti bahwa wasiat tersebut diucapkan, ditulis, atau dikehendaki, tetapi pelaksanaannya didasarkan pada alasan-alasan hukum yang membenarkan bahwa wasiat tersebut harus dilaksanakan. ${ }^{37}$

Term Wasiat Wasiat wajibah hanya ada dalam hukum Indonesia dan tidak ditemukan di negara lain. Wasiat Wajibah secara logal formal tertulis dalam KHI sebagaimana telah dijelaskan diatas. Tujuan wasiat wajibah dimasukkan ke dalam KHI adalah untuk melakukan pendekatan kompromi dengan hukum adat. Hal ini dilakukan bukan hanya sebatas pengambilan nilai-nilai hukum adat untuk diangkat dan dijadikan ketentuan hukum Islam. Pendekatan kompromistis ini, termasuk juga dalam hal memadukan pengembangan nilai-nilai hukum Islam yang sudah ada nashnya dengan nilai-nilai hukum adat. Tujuannya agar ketentuan hukum Islam itu lebih dekat dengan kesadaran hidup masyarakat. Hal ini dapat dikatakan sebagai islamisasi hukum adat sekaligus seiring dengan upaya mendekatkan hukum adat ke dalam hukum Islam. ${ }^{38}$

\footnotetext{
35 Lihat Kompilasi Hukum Islam Bab V pasal 194 - 209.

36 Ahmad Junaidi, 2013, Wasiat Wajibah, Yogyakarta: Pustaka Pelajar, hal. 1.

37 Ahmad Junaidi, 2013, Wasiat Wajibah, Yogyakarta: Pustaka Pelajar, hal. 118.

38 Ahmad Junaidi, Wasiat Wajibah, (Yogyakarta: Pustaka Pelajar, 2013), hal. 163.
} 
Ada perkara yang mempermasalahkan kedudukan anak angkat yang tidak melalui proses keputusan pengadilan sesuai dengan pasal 171 huruf h, KHI dan juga tidak merujuk pada surat edaran Mahkamah Agung tanggal 7 April 1979 No.2 tahun 1979 tentang Pengangkatan Anak, yaitu terdapat pada putusan Mahkamah Agung Nomor 312 K/ AG/2010. Dalam putusan tersebut tidak dimasalahkan kedudukan anak angkat yang tidak berdasarkan keputusan pengadilan tetapi hakim menggunakan hukum adat kebiasaan yaitu tertuang dalam Undang-undang No.4 Tahun 1976 sebagaimana dalam judex facti pengadilan sebelumnya. Dalam Undang-undang Nomor 4 Tahun 1979 tentang Kesejahteraan Anak, pasal 1 ayat (2) menyebutkan bahwa "anak adalah seseorang yang belum mencapai umur 21 tahun dan belum pernah menikah".

Dalam kaitannya dengan putusan tersebut, menurut putusan Mahkamah Agung bahwa judex facti tidak salah dalam menerapkan hukum, lagi pula hal ini mengenai hasil pembuktian yang bersifat penghargaan tentang suatu kenyataan, hal mana tidak dapat dipertimbangkan dalam pemeriksaan tingkat kasasi, karena pemeriksaan tingkat kasasi hanya berkenaan dengan tidak dilaksanakan atau ada kesalahan dalam penerapan atau pelanggaran hukum yang berlaku.

Selain itu juga berkaitan dengan pengangkatan anak, salah satu yang dipersoalkan dalam putusan pengadilan adalah syarat yang harus terpenuhi adalah dalam hal pengangkatan anak yang muncul dalam putusan Mahkamah Agung Nomor 312 K/ AG/2010. Selain telah disebutkan dalam Kompilasi Hukum Islam (KHI), persyaratan anak angkat juga diangkat dalam Surat Edaran Mahkamah Agung tanggal 7 April 1979 No.2 tahun 1979 tentang Pengangkatan Anak, dikatakan bahwa; "Pengesahan Pengangkatan Anak Warga Negara Indonesia hanya dapat dilakukan dengan suatu penetapan di Pengadilan Negeri, dan tidak dibenarkan apabila pengangkatan anak tersebut dilakukan dengan akta notaris yang di legalisir oleh Pengadilan Negeri" ${ }^{39}$

Peraturan mengenai pengangkatan anak tidak hanya dalam KHI dan Surat Edaran Mahkamah Agung No. 2 Tahun 1979 itu saja, tetapi ada beberapa peraturan yang berkaitan dengan pengangkatan anak, diantara beberapa peraturan tersebut adalah:

a. Undang-Undang Nomor 4 Tahun 1979 Tentang Kesejahteraan Anak

39 Muderis Zaini, Adopsi Suatu Tinjauan Dari Tiga Sistem Hukum, (Jakarta : Sinar Grafika, 1995), hal. 112. 
b. Surat Edaran Mahkamah Agung Nomor 6 Tahun 1983 tentang Penyempurnaan Surat Edaran Nomor 2 Tahun 1979.

c. Surat Edaran Mahkamah Agung Nomor 4 Tahun 1989 tentang Pengangkatan Anak

d. Undang-Undang Nomor 23 Tahun 2002 Tentang Perlindungan Anak

e. Surat Edaran Mahkamah Agung Nomor 3 Tahun 2005 tentang Pengangkatan Anak

f. Undang-Undang Nomor 12 Tahun 1989 Tentang Kewarganegaraan Republik Indonesia

g. Undang-Undang Nomor 7 Tahun 2006 Tentang Peradilan Agama dan telah diubah dengan Undang-Undang Nomor 3 Tahun 2006.

h. Peraturan Pemerintah Nomor 54 Tahun 2007 Tentang Pelaksanaan Pengangkatan Anak

i. Peraturan Menteri Sosial RI Nomor 110/HUK/2009 Tentang Persyaratan Pengangkatan Anak.

Dari peraturan-peraturan tersebut yang diangkat dalam perkara adalah berkaitan dengan persyaratan pengangkatan anak yang tertuang didalam KHI dan Surat Edaran Mahkamah Agung No. 2 Tahun 1979, namun demikian yang dijadikan dasar hukum oleh putusan judex facti adalah Undang-Undang Nomor 4 Tahun 1979 Tentang Kesejahteraan Anak khususnya pasal 12 ayat (1) dan (2).

Untuk kepentingan masa depan anak, pengangkatan anak justru harus di dorong oleh pemerintah demikian juga oleh lembaga-lembaga peradilan di Indonesia, jangan sampai ada pertimbangan hukum normatif yang justru mengekang keberadaan anak angkat termasuk hak-haknya dalam pembagian harta, sehingga anak angkat dan orang tua angkat memiliki ikatan kuat secara emosional.

Tujuan pengangkatan anak adalah dalam rangka melindungi kesejahteraan anak dan perlindungan anak tersebut. Secara normatif tujuan pengangkatan anak dapat dijumpai dalam Pasal 2 Peraturan Pemerintah Nomor 54 Tahun 2007 dan Surat Edaran Mahkamah Agung RI Nomor 6 Tahun 1083.

Selain beritan dengan pengangkatan anak, putusan Mahkamah agung juga berkaitan dengan bagian anak angkat dan anak tiri. Menyamakan bagian anak 
tiri (anak bawaan) dengan anak angkat dijumpai dalam putusan Mahkamah Agung Nomor 489 K/AG/2011. Dalam perkara ini anak tiri dan anak angkat berasal dari ibu yang berbeda. Dalam perkara tersebut Hakim Agung Mukhtar Zamzami berpendapat bahwa anak tiri bukanlah ahli waris dan bukan pula zawil arkham, maka tidak ada alasan hukum apapun untuk menyerahkan sisa harta warisan kepada mereka dan anak tiri juga tidak bisa dibandingkan dengan anak angkat. Tetapi dalam putusan Mahkamah Agung Nomor 489 K/ AG/2011 anak tiri dan anak angkat mendapat bagian yang sama.

Sejauh ini, di Indonesia belum ada ketentuan tegas masalah kedudukan anak tiri dalam hukum Islam, juga belum secara tegas menjadi putusan pengadilan yang telah menjadi jurisprodensi. Secara normatif hakim bukan sekedar "bouche de la loi", tetapi menjadi penterjemah atau pemberi makna melalui penemuan hukum (rechtsvinding) bahkan menciptakan hukum baru (rechtschepping) melalui putusan-putusannya (judge made law). ${ }^{40}$ Dalam putusan Mahkamah Agung Nomor 489 K/AG/2011 tidak ada pertimbangan hukum yang dipakai sehingga putusan dengan memberikan bagian yang sama dalam pembagian harta peninggalan tidak ada sumber rujukan.

Anak tiri adalah anak bawaan isteri atau suami akibat perkawinan yang sah, sedangkan dalam pasal. 43 ayat (1) Undang Undang Nomor 1 Tahun 1974 Tentang Perkawinan jo. pasal. 186 KHI, disebutkan bahwa anak tiri adalah anak bawaan isteri yang lahir di luar perkawinan sah, dengan demikian dia hanya mempunyai hubungan saling mewarisi dengan Ibunya dan keluarga dari pihak Ibunya tersebut. ${ }^{41}$

Posisi Anak tiri manakala dibandingkan dengan anak angkat, maka posisi anak tiri ini "terkadang" tidak lebih baik dari anak angkat. Apabila kehadiran anak angkat secara penuh diterima oleh Kedua orang tua angkatnya, karena memang dikehendaki kehadirannya, maka tidak demikian halnya dengan anak tiri. Kehadiran anak tiri "terkadang" tidak diterima secara penuh oleh Ibu atau Bapak tirinya. Bisa saja terjadi bahwa seseorang hanya bisa menerima Ibu atau Bapaknya saja (dari anak tiri). Karena memang yang dinikahi itu adalah Ibu

${ }^{40}$ Lingkungan Peradilan Agama, Mahkamah Agung RI., 1 Juli 2003 M, Suara Uldilag., Pokja. Perdata Agama MA-RI, Jakarta, Edisi II; hal. 8.

${ }_{41}$ Departemen Kehakiman RI., II/1985, Undang-Undang Perkawinan Dan peraturan pelaksanaannya, Jakarta, hal. 13 - Departemen Agama RI., 1991/1992, Kompilasi Hukum Islam, Jakarta., hal. 95. 
atau Bapaknya (saja), dan bukan dengan anak-anaknya itu (anak tiri). Pandangan seperti ini tentu lahir dari mereka yang beranggapan bahwa pernikahan hanyalah mengikat bagi mereka berdua (suami-isteri) saja, tidak lebih dan tidak kurang.

Posisi anak tiri seperti tersebut di atas, maka bagi Anak tiri yang arang tua kandungnya, berkecukupan harta "mungkin" tidak begitu menjadi masalah yang berarti. Akan tetapi apabila orang tua kandungnya (dari anak tiri) kurang berkecukupan, maka masalah harta menjadi sangat berarti baginya, demi menunjang kesejahteraan hidupnya di masa kini dan yang akan datang, baik untuk pendidikan, pengobatan dan pembinaan lainnya.

Berdasarkan keputusan Mahkamah Agung tersebut diatas yang menyamakan bagian anak tiri dengan bagian anak angkat menurut peneliti sebagaimana pendapat Ahmad Muntoha, menggunakan metode Qiyas, yaitu diqiaskan dengan anak angkat, sehingga kepadanya dapat pula diberikan bagian dari harta warisan Ibu atau Bapak tirinya, melalui modifikasi dari konsturksi Hukum Wasiat wajibah sebanyak-banyaknya 1/3 dari harta warisan Ibu atau Bapak tirinya.

Anak angkat dan anak tiri mempunyai persamaan kenyataan alasan ('illat) bahwa mereka ini adalah anak orang lain yang dengan sengaja dimasukkan menjadi bagian dari satu keluarga dengan tetap mempertahankan jati diri mereka sebagai anak orang lain demi tetap terpeliharanya "hifdzun Nasl".

Pemberian seperti tersebut di atas, juga mempunyai fungsi yang sama dengan pemberian kepada Anak angkat yaitu untuk melindungi dan menjamin kesejarteraan mereka yang ada di dalam tangungjawab satu keluarga. Bukankah Allah SWT. juga telah menganjurkan tindakan pengentasan seperti ini, sebagaimana termaktup dalam Al-Qur'an surah Al Ahzaab ayat 6. ${ }^{42}$

\section{F. Penutup}

Keputusan Mahkamah Agung RI tentang Wasiat Wajibah dari putusan tahun 2006 - 2012 secara umum mengacu pada Instruksi Presiden Republik Indonesia Nomor 1 Tahun 1991 tentang Kompilasi Hukum Islam (KHI) dan ada beberapa

${ }^{42}$ Lihat Ahmad Munthohar, "Anak Tiri, dalam Perspektif Hukum Kewarisan Islam”, dikutip dari www.pa-banjarnegara.go.id. 
pertimbangan hukum yang mengiringinya, diantaranya pertimbangan hukum yang mengacu pada hukum adat dan Undang-Undang Nomor 4 Tahun 1979. Selain itu, berkaitan dengan wasiat wajibah, Mahkamah Agung secara khusus menerbitkan surat edaran Mahkamah Agung tanggal 7 April 1979 Nomor 2 Tahun 1979 Tentang Pengangkatan Anak yang konsekuensi hukumnya adalah adanya wasiat wajibah dalam hal pembagian harta peninggalan. Pada putusanputusan Mahkamah Agung tersebut tidak ditemukan Hakim Agung merujuk pada paraturan lain selain KHI dan tidak pula ditemukan Hakim Agung membuat putusan sendiri diluar apa yang telah tertulis dalam KHI.

Dalam KHI pasal 195 ayat (2), wasiat hanya diperbolehkan sebanyak-banyaknya sepertiga dari harta warisan kecuali apabila semua ahli waris menyetujui. Besaran ini sama dengan besaran bagian untuk anak angkat yang diatur dalam pasal 209 ayat (2), yaitu terhadap anak angkat yang tidak menerima wasiat diberi wasiat wajibah sebanyak-banyaknya $1 / 3$ dari harta warisan orang tua angkatnya.

Ada perkara yang mempermasalahkan pengangkatan anak angkat yang tidak melalui proses keputusan pengadilan sesuai dengan pasal 171 huruf h, KHI dan juga tidak merujuk pada surat edaran Mahkamah Agung tanggal 7 April 1979 No.2 tahun 1979 tentang Pengangkatan Anak, yaitu terdapat pada putusan Mahkamah Agung Nomor 312 K/AG/2010. Dalam putusan tersebut tidak dimasalahkan kedudukan anak angkat yang tidak berdasarkan keputusan pengadilan tetapi hakim menggunakan hukum adat kebiasaan yaitu tertuang dalam Undang-undang No.4 Tahun 1976 sebagaimana dalam judex facti pengadilan sebelumnya. Dalam Undang-undang Nomor 4 Tahun 1979 tentang Kesejahteraan Anak, pasal 1 ayat (2) menyebutkan bahwa "anak adalah seseorang yang belum mencapai umur 21 tahun dan belum pernah menikah".

Persoalan wasiat wajibah tidak hanya diberikan kepada anak angkat tetapi juga kepada anak tiri, ada perdebatan yang manarik dalam perkara yang telah diputuskan oleh Mahkamah Agung RI yaitu putusan Nomor 489 K/AG/2011. Putusan tersebut pada intinya menyamakan bagian anak tiri (anak bawaan) dengan anak angkat. Sejauh ini, di Indonesia belum ada ketentuan tegas masalah kedudukan anak tiri dalam hukum Islam, juga belum secara tegas menjadi putusan pengadilan yang telah menjadi jurisprodensi.

Menyamakan bagian anak tiri dengan bagian anak angkat mungkin Ha- 
kim Agung menggunakan metode Qiyas, yaitu diqiaskan dengan anak angkat, sehingga kepadanya dapat pula diberikan bagian dari harta warisan Ibu atau Bapak tirinya, melalui modifikasi dari konsturksi Hukum Wasiat wajibah sebanyak-banyaknya 1/3 dari harta warisan Ibu atau Bapak tirinya.

Anak angkat dan anak tiri mempunyai persamaan kenyataan alasan ('illat) bahwa mereka ini adalah anak orang lain yang dengan sengaja dimasukkan menjadi bagian dari satu keluarga dengan tetap mempertahankan jati diri mereka sebagai anak orang lain demi tetap terpeliharanya "hifdzun Nasl".

Rekomendasi dari penelitian ini adalah; pertama, dalam penelitian ini peneliti belum menemukan hakim melakukan ijtihad hukum selain yang telah tertulis dalam Undang-undang atau peraturan tertulis sejenisnya, oleh sebab itu perlu menghidupkan tradisi menemukan hukum, sehingga hakim tidak hanya sekedar "hakim peraturan" tetapi seorang yang memutuskan perkara dengan berbagai sumber yang melingkupi perkara. Oleh sebab itu perlu membuka kembali mandegnya tradisi ijtihad hakim. Kedua, dalam pengembangan hukum diperlukan adanya perhargaan kepada hakim yang kreatif, berani menemukan hukum dan ijtihad yang rasional proporsional bagi lahirnya hukum adil dan mensejahterkan.

\section{DAFTAR PUSTAKA}

Ahmad Junaidi, 2013. Wasiat Wajibah. Yogyakarta: Pustaka Pelajar.

Ahmad Munthohar, Anak Tiri, dalam Perspektif Hukum Kewarisan Islam, dikutip dari www.pa-banjarnegara.go.id.

Al-Buthi, Ramadhan. 2001. Dawabith al-Maslahah al-Syari'ah al-Islamiyah. Beirut, Libanon: Al-Muassasah al-Risalah.

Al-Buti, Muhammad Sa'id Ramdan. 1977. Dawabit al-Maslahah fi as-Syariah alIslamiyah. Beirut: Mu'assasah ar-Risalah.

Ali, M. Sayuthi. 2002. Metodologi Penelitian Agama; Pendekatan Teori dan Praktek. Jakarta: PT RajaGrafindo Persada.

Ash Shiddiqy, Muhammad Hasbi. 1973. Fikih Mawaris. Jakarta: Bulan Bintang. . 1999. Fiqih Mawaris. Semarang: PT. Pustaka Rizki Putra.

Budi Hardiman, Francisco. 1990. Kritik Ideologi: Pertautan Pengetahuan dan Kepentingan. Yogyarakarta: Penerbita Kanisius. . 1993. Mепијu Masyarakat Komunikatif. Yogyakarta: Kanisius. 
Dahlan, Abdul Aziz (ed). Tt. Ensiklopedi Hukum Islam. Jilid. 6. Jakarta: Ichtiar Baru van Hove.

Departemen Kehakiman RI., II/1985, Undang-Undang Perkawinan Dan peraturan pelaksanaannya, Jakarta, hal. 13 - Departemen Agama RI., 1991/1992, Kompilasi Hukum Islam, Jakarta.

Departemen Pendidikan dan Kebudayaan RI. 1997. Kamus Besar Bahasa Indonesia, (Jakarta: Balai Pustaka.

Djamil, Fathurrahman. 1999. “Wasiat: Makna, Urgensi dan Kedudukannya dalam Islam" dalam Mimbar Hukum, 1999, Nomor 38 Tahun IX.

Dolianti, dkk. 2013. "Pembagian Harta Waris Orang Yang Berbeda Agama (Suatu Studi Atas Putusan Mahkamah Agung RI Nomor 51 K/AG/1999)" dalam Tesis. Bengkulu: Fakultas Hukum UNIB.

Fatchurrahman. 1979. Wasiat Wajibah. Dalam Majalah UNISIA, Plaatsvervulling. Yogyakarta: Universitas Islam Indonesia.

Fauzan, Uzair dan Prasetyo, Heru. 2006. Teori Keadilan. Yogyakarta: Pustaka Pelajar.

Friedrich,Carl Joachim. 2004. Filsafat Hukum Perspektif Historis. Bandung: Nuansa dan Nusamedia.

Hamidi, Jazim. 2005. Hermeneutika Hukum. Yogyakarta, UII Press.

Instruksi Presiden Republik Indonesia Nomor 1 Tahun 1991 tentang Kompilasi Hukum Islam.

Iscahyanto, Dheddy. 2005. “Analisis Yuridis Wasiat Wajibah Sebagai Salah Satu Cara Mendapatkan Bagian Bagi Anak Angkat (Studi Kasus Putusan Nomor: 1326/Pdt.G/2006/PA.TA dan Putusan Nomor: 07/ Pdt.G/2008/PTA.Sby)" dalam Tesis. Yogyakarta: FH-UGM.

Kerlenger, Fred N. 1996. Asas-Asas Penelitian Behaviorial. Yogyakarta: Gajah Mada University Press.

Khadduri, Majid. 1984. The Islamic Conception of Justice. London: The Jhons Hopkins Press Ltd.

Khadduri, Majid. 1999. Teologi Keadilan Perspektif Islam. Alih bahasa Mochtar Zoeni dan Joko S. Kahhar. Cet. 1. Surabaya: Risalah Gusti.

Krisnajadi. 1989. Bab-bab Pengantar Ilmu Hukum. Bandung: STHB.

Lingkungan Peradilan Agama, Mahkamah Agung RI., 1 Juli 2003 M, Suara Uldilag., Pokja. Perdata Agama MA-RI, Jakarta, Edisi II. 
Magnis-Suseno, Franz. 1992. Filsafat Sebagai Ilmu Kritis. Yogyakarta: Kanisius. Mas'ud, Muhammad Khalid. 1989. Islamic Legal Philosophy a Study of Abu Ishaq al-Shatibi's Life and Thought. Delhi: International Publisher.

Mas'udi, Masdar F. 1995. "Meletakkan Kembali Maslahat Sebagai Acuan Syari'ah" dalam Jurnal Ilmu dan Kebudayaan Ulumul Qur'an. No.3, Vol. VI Th. 1995.

Maulana, Zaldin Abdi. 2013. “Kajian Yuridis Tentang Wasiat Wajibah Kepada Ahli Waris Non Muslim Menurut Hukum Waris Islam (Studi Putusan Mahkamah Agung RI Nomor 368. K/AG/1995)" dalam Tesis. Jember: Fakultas Hukum Universitas Jember.

Miles. Mattew B. and Huberman, A. Michael. 1992. Analisis Data Kualitatif: Buku Sumber tentang Metode-metode Baru. Jakarta: UI Press.

Misrawi, Zuhairi dan Novriantoni. 2004. Doktrin Islam Progresif; Memahami Islam Sebagai Ajaran Rahmat. Jakarta: LSIP.

Moelong, Lexy J. 1989. Metode Penelitian Kualitatif. Bandung: Remaja Rosdakarya.

Muderis Zaini. 1995. Adopsi Suatu Tinjauan Dari Tiga Sistem Hukum. Jakarta: Sinar Grafika.

Muhammad, Abdulkadir. 2004. Hukum dan Penelitian Hukum. Bandung: PT.Citra Aditya Bakti.

Nadia, Nike. 2013. “Studi Kasus Putusan Mahkamah Agung Republik Indonesia No 16 K/Ag/ 2010 Tentang Hak Mewaris Istri Non Muslim dari Suami Yang Beragama Islam Dihubungkan Dengan Hukum Waris Islam dan Instruksi Presiden Nomor 1 Tahun 1991 Tentang Kompilasi Hukum Islam" dalam Repository Jurnal FH Universitas Padjadjaran. Bandung.

Nazir, Muhammad. 1988. Metode Penelitian. Jakarta: Ghalia Indonesia. Putusan Mahkamah Agung Republik Indonesia Nomor: 102_K_AG_2006 Putusan Mahkamah Agung Republik Indonesia Nomor: 13-K-AG-2007 Putusan Mahkamah Agung Republik Indonesia Nomor: 145_K_AG_2010 Putusan Mahkamah Agung Republik Indonesia Nomor: 216_K_TUN_2006 Putusan Mahkamah Agung Republik Indonesia Nomor: 307_K_AG_2009 Putusan Mahkamah Agung Republik Indonesia Nomor: 312_K_AG_2010 Putusan Mahkamah Agung Republik Indonesia Nomor: 318-K-AG-2008 Putusan Mahkamah Agung Republik Indonesia Nomor: 338_K_AG_2009 
Putusan Mahkamah Agung Republik Indonesia Nomor: 364_K_AG_2011

Putusan Mahkamah Agung Republik Indonesia Nomor: 443_K_AG_2011

Putusan Mahkamah Agung Republik Indonesia Nomor: 482_K_AG_2008

Putusan Mahkamah Agung Republik Indonesia Nomor: 489_K_AG_2011

Rawls, John. 1973. A Theory of Justice. London: Oxford University press.

Rofiq, Ahmad. 2003. Hukum Islam di Indonesia. Jakarta: PT. Raja Grafindo Persada.

Rusyd, Ibnu. T.t. Bidayatul Mujtahid. Juz II. Semarang: Usaha Keluarga.

Soekanto, Soerjono dan Mamudji, Sri. 2001. Penelitian Hukum Normatif, Suatu Tinjauan Singkat. Jakarta: Raja Grafindo Persada.

Soekanto, Soerjono. 1986. Pengantar Penelitian Hukum. Cetakan ke-2. Jakarta: UI Press.

Soekanto, Soerjono. 1986. Pengantar Penelitian Hukum. Jakarta: UI Press.

Sunggono, Bambang. 1998. Metodologi Penelitian Hukum. Cetakan ke-2. Jakarta: Rajawali Pres.

Susanti, Fitri. 2012. “Wasiat Wajibah Bagi Anak Angkat Menurut Kompilasi Hukum Islam ( Studi Kasus Putusan Mahkamah Agung Nomor 338 K/ AG/2009)" dalam Tesis. Yogyakarta: FH-UGM.

Undang-undang Mahkamah Agung Tahun 1985 No. 14.

Usman, Husain dan Akbar, Purnomo Setiady. 2003. Metodologi Penelitian Sosial, Cetakan ke-3. Jakarta: Bumi Aksara.

Vago, Steven. Tt. Law and Society. New Jersey: Prentice Hall Englewood Cliffs. 